\title{
WELFARE EFFECTS OF LABOR MIGRATION
}

\section{Dmytro Vikhrov}

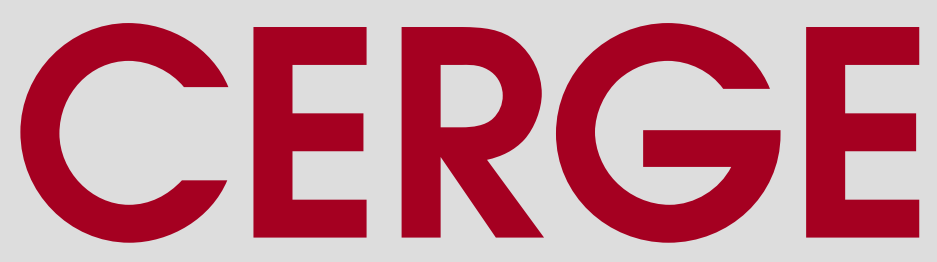

Charles University

Center for Economic Research and Graduate Education

Academy of Sciences of the Czech Republic

Ec onomic Institute 


\title{
Working Paper Series \\ 491 (ISSN 1211-3298)
}

Welfare effects of labor migration

\author{
Dmytro Vikhrov
}

\section{CERGE-EI}

Prague, September 2013 
ISBN 978-80-7343-295-9 (Univerzita Karlova. Centrum pro ekonomický výzkum a doktorské studium)

ISBN 978-80-7344-287-3 (Národohospodářský ústav AV ČR, v.v.i.) 


\title{
Welfare effects of labor migration
}

\author{
Dmytro Vikhrov* \\ CERGE-EI
}

\begin{abstract}
The developed theoretical model analyzes the welfare effects of labor migration. I find that for the receiving country immigration enhances welfare as long as the marginal benefits to the natives' income exceed the social costs of immigration. Over-emigration of workers generated by free mobility is welfare detrimental to the source country because of the diaspora effect - migrants negatively affect their own income. The source country prefers to coordinate the immigration quota with the destination country, because the coordinated solution internalizes the negative diaspora effect. Contrary to popular opinion, under certain conditions unilateral enforcement of the immigration quota benefits the source country also, because it reduces the extent of the migrants' income decline.
\end{abstract}

\begin{abstract}
Abstrakt
Vytvořený teoretický model analyzuje dopady migrace pracovní síly na prosperitu. Zjištuji, že imigrace zvyšuje prosperitu přijímající země, pokud mezní prŕrůstek příjmu pưvodních obyvatel převyšuje sociální náklady imigrace. Př́liš vysoká emigrace pracovníki̊, zapřričiněná volným pohybem osob, snižuje prosperitu země původu z důvodu efektu diaspory - migranti negativně ovlivňují svůj vlastní př́ijem. Země původu dává přednost koordinaci imigračních kvót s přijímající zemí, protože koordinace internalizuje negativní efekt diaspory. V kontrastu s populárním názorem, za určitých podmínek jednostranné prosazování imigrační kvóty prospívá i zemi původu, protože snižuje rozsah poklesu př́jmu migrantů.
\end{abstract}

Keywords: migration costs, wage effect, immigration policy, coordination JEL Classification: F22, J15, D61, E61

*I am grateful to my supervisor Byeongju Jeong for guidance in writing this paper. E-mail: dmytro.vikhrov@cerge-ei.cz.

${ }^{\dagger}$ A joint workplace of the Center for Economic Research and Graduate Education, Charles University, and the Economics Institute of the Academy of Sciences of the Czech Republic.

Address: CERGE-EI, P.O. Box 882, Politických vězňů 7, Prague 11121, Czech Republic. 


\section{Introduction}

Zimmermann (1995) notes that the European countries ${ }^{1}$ started restricting immigration flows after the first oil price shock in 1973, because it sparked fears of social tension and unemployment. Since then policy makers have been contemplating about the optimal immigration policy, which, in principle, should address the issues of immigration quota, immigrants' characteristics, their rights to employment, family reunification, access to welfare and citizenship. In 2011 the UK introduced an annual immigration cap of 20 thousand on non-EU immigration plus 1 thousand in "exceptional talent" visas. Inter-company transfers, though not affected by this regulation, face restriction on earnings and duration of stay. In the US for the 2014 fiscal year the annual cap on H-1B category visas is 65 thousand. The intention is, due to high demand from employers, to distribute visas on a lottery basis. The Australian migration program for 2012-2013 is set for 190 thousand places, out of which $68 \%$ is reserved for skilled migrants. Following its immigration levels plan for 2013, Canada should accept 260 thousand migrants, out of which $62.3 \%$ are economic migrants. ${ }^{2}$

Despite the relevance of the issue for policy makers, the existing literature on the immigration policy is quite inconclusive. Giordani and Ruta (2011) note that existing theoretical models predict polarized immigration outcomes; either too many migrants or the closed door policy. The mismatch between theoretical predictions and practical outcomes calls for more research into the welfare effects of immigration, which is the driving force behind immigration policy. ${ }^{3}$ Since the migration event involves three actors, namely, migrants, sending and receiving countries, there is a need for a theoretical framework that allows for a consistent comparison across them. This paper develops such a model. Specific questions addressed are: "How does immigration affect the welfare of the destination country?", "How does emigration affect the welfare of the source country?", "How many

\footnotetext{
${ }^{1}$ The reference is made to members of the European Economic Community as of 1974: France, Germany, Italy, Belgium, the Netherlands, Luxembourg, UK, Ireland and Denmark.

${ }^{2}$ This information is taken from respective official government web sites: www.ukba.homeoffice.gov.uk, www.uscis.gov, www.cic.gc.ca, and www.immi.gov.au.

${ }^{3}$ There is also insufficient empirical research on quantifying the immigration policy. Ortega and Peri (2009) create an index that measures toughness of entrance and asylum laws, however, their measure is not heterogeneous across sending countries. Docquier et al. (2012) quantify the immigration policy by the fraction of refugees and females among migrants and existence of bilateral guest worker programs.
} 
migrants move under free mobility?", and "What are the gains from coordinating a joint immigration policy?". Answering these questions in a unified framework sheds light on the structure of incentives of the actors, which helps explain the South-North migration.

This paper models only labor migration. According to data in Section 2 it accounts for no more than $40 \%$ of the incoming flows, the rest being mainly family-related migration. In most cases a worker moves first and is then followed by a spouse who is a "tied" mover (collective theory of family migration: Mincer, 1978 and Rabe, 2011).

In his seminal paper Borjas (1995a) finds that immigration decreases natives' wages, redistributes wealth from workers to capital owners and creates an immigration surplus. The author argues that skilled immigration generates a larger surplus because skilled wages are more responsive to a shift in labor supply. For the US economy Storesletten (2000) finds that high-skilled migrants aged 40-44 are the most beneficial from the fiscal standpoint. For Germany, Akin (2012) finds that, at 2011 immigration rates the country's welfare is enhanced by around 3\%. In his model with agents heterogeneous in wealth holdings Benhabib (1996) finds that if migrants decrease the capital/labour ratio, then those locals with above-average capital will have higher post-immigration income. The mirror image of this finding is also true, in that if the capital/labour ratio is increased by migrants, then those with below-average capital will have higher post-immigration income. Under majority voting the voters will be divided into those who prefer admitting migrants with either high or low wealth holdings. Bertoli and Brucker (2011) find that the shift towards a more selective immigration policy, without increasing the immigration volume, is always welfare detrimental to the source country. In their theoretical model, Razin and Sadka (1999) find that unskilled immigration into a welfare state with a payas-you-go pension system is strictly beneficial to all age groups. Fuest and Thum (2000) investigate the welfare effects of immigration when some sectors are unionized. They find that immigration is beneficial if the wage elasticity of labor demand in the competitive sectors is smaller than in the unionized one. In the opposite case small (large) scale immigration reduces (increases) locals' welfare.

Recent studies emphasize the role of social immigration costs, which include, but are not limited to, migrants' participation in welfare programs, ${ }^{4}$ costs of border control

\footnotetext{
${ }^{4}$ Ostrovsky (2012), Borjas (2011) provide evidence that migrants do participate in welfare programs.
} 
and policing ${ }^{5}$ and locals' dissatisfaction from having migrants in the neighbourhood. ${ }^{6}$ Giordani and Ruta (2011) define social costs as the fiscal and integration costs of the immigrant community. The authors argue for the presence of "congestion effects", when it becomes more difficult to integrate an additional migrant beyond a certain threshold. Schiff (2002) finds that immigrants decrease the social capital in the host society by increasing its diversity.

For the sending country the welfare effects of emigration are associated with how the income of stayers and migrants is affected by the marginal moving worker. I find that emigration decreases output in the source country by the migrants' wage leaving the income of stayers unaffected. Besides that, emigration generates a negative diaspora effect; a marginal migrant decreases the income of other migrants. The literature has two hypotheses on this issue; brain gain and brain drain. The brain drain literature finds that the emigration of skilled workers deprives the source country of the human capital that is important for its economic growth. Bhagwati and Hamada (1982) suggest taxing skilled emigrants and using the proceeds for developmental spending in the country of origin. $^{7}$ Burda and Wyplosz (1992) find that the market delivers too much migration relative to the social planner's outcome, because it ignores the external social costs. The authors suggest introducing a labor subsidy in the source country and a one-shot tax on emigrants. Cellini (2007) finds that emigration always lowers the welfare of the sending country because it decreases the average level of human capital and the labor productivity. The author argues that when immigration entails positive welfare effects for the receiving country, it is willing to accept more migrants than is optimal. The literature on brain gain (Mountford, 1997; Stark et al., 2004; Batista et al., 2012) concludes that under certain conditions the sending country benefits from skilled emigration, because out of all prospective migrants who study more to boost their chances to emigrate, only a fraction will eventually emigrate and the remaining non-migrants will increase the average

The rate and character of participation differs by the destination country, migrants' demographic characteristics and their duration of stay.

${ }^{5}$ The total budget of Frontex, the EU agency for border control, was EUR 86.8 million in 2011 (Frontex, 2011). This excludes the costs of policing measures of individual EU member states.

${ }^{6}$ Filer (1992) finds that the attractiveness of a city for the local workers negatively correlates with the volume of the recent immigrant population.

${ }^{7}$ Such a tax has not been introduced in practice, though some developing countries issue diaspora bonds, which bear a rather voluntary character (Ketkar and Ratha, 2010). 
level of human capital. For example, for Cape Verde Batista et al. (2012) find that "a $10 \mathrm{pp}$ increase in the probability of their own future migration improves the probability of completing intermediate secondary schooling by nearly $4 \mathrm{pp}$ for individuals who do not migrate before age $16 "$.

The model developed here predicts that a moving worker lowers the wage in the migrant sector of the destination country affecting the income of native and migrant workers. The negative effect of migrants on their own income (diaspora effect) is supported by several empirical studies. Using the example of the construction sector in Norway, Bratsberg and Raaum (2012) find that the wage effect varies across education groups. For the low and medium educated natives and migrants it is similar in magnitude and significance, whereas it is zero for the skilled natives and negative for the skilled migrants. A $10 \%$ increase in immigrant employment decreases native wages in construction by $0.6 \%$. Borjas (1987b) finds that a 10\% increase in the supply of immigrants reduces the immigrant wage by about 10\%. LaLonde and Topel (1991) report that a $10 \%$ increase in new immigration reduced wages of new immigrants by $0.24 \%$. The studies find that in the long run the reported negative effect disappears because of the adjustments: locals out-migrate from areas (Filer, 1992) or exit sectors (Bratsberg and Raaum, 2012) with a high concentration of immigrants, and new industries locate in places with a relatively large supply of unskilled labor.

In the paper I first provide documentation on migration and evidence of coordination of immigration policies on the EU level. In the model section I first describe economies of countries A and B. Then I formalize the migration preference of individual workers, the immigration preference of receiving Country A, the emigration preference of sending Country B and the preference of the political union. I further compare the four outcomes and conclude. 


\section{Documentation on migration}

Migration is a bilateral phenomenon. It is established between a pair, or groups, of countries and evolves over time. The world migration picture is quite diverse and dynamic. Data in Figure 1 suggest that in 1990 migration within the developing world (SouthSouth) ranked first in volume and accounted for almost $40 \%$ of the total stock of migrants, ${ }^{8}$ whereas migration within the developed world (North-North) and the developing to developed world (South-North) ranked second and third with respective shares of $27.1 \%$ and $25.7 \%$. By 2000 the world workforce became significantly more mobile and total migration grew by around $38.2 \%$. The growth was primarily driven by the increase in South-North migration (86.2\%), which surpassed all other flows in volume and in 2000 totaled 74.3 million people or $34.7 \%$ of the total migrant stock.

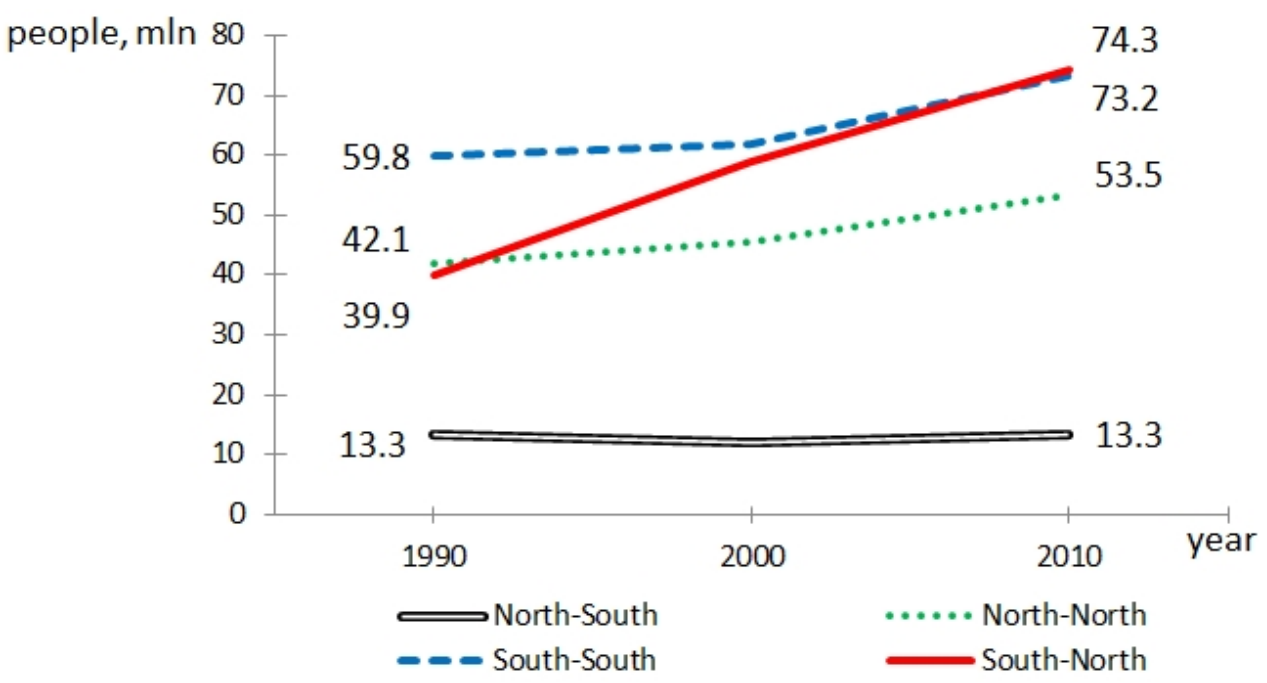

Figure 1: International migrant stock (in mln) by source and destination region. Source: United Nations (2011).

Several factors stand behind the rapid growth of South-North migration. The definition of "North" in 2000 includes more countries than in 1990. The developed economies need young migrant workers to satisfy labor shortages and support the ageing population, among other reasons. The developing world has got wealthier and migration costs have

\footnotetext{
${ }^{8}$ There is no convention on what defines a migrant and destination countries use their national definition. To avoid data inconsistency in the cross-country comparison, OECD standardizes the migration statistics. In many instances OECD and UN define a migrant as a foreign-born individual. Unless otherwise noted, I will keep to this definition throughout the text. See OECD (2012) and United Nations (2011) for a detailed discussion on national definitions.
} 
declined in many ways, making it easier for people in the source countries to satisfy the migration budget constraint.

Realization of the event of economic migration entails two selection effects. Only those individuals emigrate who expect to benefit from emigration. ${ }^{9}$ Out of the pool of potential migrants the immigration policy admits those who meet selection criteria as long as the quota has not been exhausted. ${ }^{10}$ These two types of selection affect all aspects of migration, viz. volume of migrants, their demographic characteristics and details of economic activity. Since only the migration outcome is observed, it is now being actively discussed how to identify the contribution of each selection type.

Table 1 in the Appendix contains basic standardized descriptive statistics. Comparing inflows and outflows in 2010 most OECD countries, except Ireland and Greece, are the net recipients of migrants. For large receiving countries in per capita terms, such as Norway, Switzerland and Austria, more than two thirds of migrants come from within the European Union, which reduces the demand of these countries for foreign labor from outside the EU. In Italy and the UK, the share of labor recruitment from outside the $\mathrm{EU}$ is $40.5 \%$ and $33.3 \%$ of total inflows respectively, whereas in most other countries this share rarely exceeds $20 \%$. Family migration accounts for a significant proportion in almost all destination countries, the largest being in the US (66.3\%), France (42.9\%) and Sweden $(39.6 \%)$. The Scandinavian countries are active in the humanitarian mission: $18.7 \%$ in Sweden, $17.4 \%$ in Finland and $9.5 \%$ of inflows in Norway are humanitarian migrants.

The migration flows translate into stocks via the law of motion. In some countries with relatively high inflows in 2010, the stocks are also high, which suggests that immigration is persistent and of a more permanent type. For example, in Switzerland, Sweden and Austria the stock of foreign-born people is $26.6 \%, 14.8 \%$ and $15.7 \%$ of the local population respectively. On the contrary, Ireland and the US have relatively low inflows in 2010 (3.9 and 3.4 migrants per one thousand of local residents), but the stocks are relatively high: $17.3 \%$ and $12.2 \%$ of the local population respectively, which suggests that the inflows

\footnotetext{
${ }^{9}$ Borjas (1987a) and Clark et al. (2007) are the key studies in the migration literature, whereas Heckman (1979) develops a general approach to address the sample selection.

${ }^{10}$ In 2012 the refusal rate in Canada was $22.5 \%$ for the permanent residence and $15.8 \%$ for the temporary residence applications. For comparison, in the US in FY 2012 the refusal rate for the non-immigrant visas was $19.6 \%$.
} 
slowed down prior to 2010. The stock of foreign nationals is usually smaller than the stock of those foreign-born, because migrants naturalize over time and disappear from the statistics on foreign nationals.

In all countries for which data are available, except Hungary and the US, the unemployment rate among the foreign-born exceeds the unemployment rate of the native born. Two comments are relevant here. Firstly, it is an established fact in the literature that migrants are disadvantaged in the labor market for some time after their arrival (literature on assimilation). Secondly, the foreign-born might be different in some underlying characteristics (education, unobservable skills and talent) for which they get penalized in the labor market. The data suggest that for all countries in the sample a migrant is more likely than a native person to have less than upper secondary education. At the same time in Austria, Hungary, Switzerland, Germany, Luxembourg and Sweden migrants are also more likely than the locals to have tertiary education. This observation suggests the polarization of migrants' education (skills); a migrant is likely to be either in the low or high education category.

The evidence on migrants' educational attainments should be reflected in their employment details. Table 2 in the Appendix provides data on employment sector and occupations of the foreign-born. In the countries considered, with the exception of Greece and Italy, the share of migrants employed in the service sector exceeds $20 \%$. In the Czech Republic and Germany more than one quarter of migrants are employed in mining, manufacturing and energy and for other countries, with the exception of Luxembourg, this share is above $10 \%$. In all countries considered $10-15 \%$ of migrants are employed in trade. In Norway, Sweden and Denmark around 20\%, in the Netherlands, Ireland and the UK around $15 \%$ of migrants are employed in the health sector. In contrast, migrants are highly unlikely to be employed in the agriculture and fishing, household (except Italy and Greece), education and administrative sectors.

Data in Table 2 also suggest that migrants are less likely to be employed in more skill demanding occupations. In elementary occupations migrants are over-represented compared to local workers in all countries considered. In professionals, senior officials and managers category migrants are more likely than locals to be employed only in Austria, Hungary, Switzerland and Luxembourg. 
The evidence thus suggests that some sectors (services, trade, mining and manufacturing, less so health care and households) and some occupations (elementary occupations, less so clerks and skilled trades) are more prone to employing migrants than other sectors and occupations. The nature of this observation is driven by immigration policy, migrants' educational attainments, language barriers, poor cross-border transferability of skills (Mattoo et al., 2008) as well as licensing and certification requirements (particularly in health care). The immigration policies of major receiving destinations often favor brain over brawn. Skill selective immigration policies have been adopted in the European Union, UK, Canada and Australia. ${ }^{11}$ Besides that, the EU member countries coordinate the immigration policies because of the common labor market within the European Economic Area.

Despite the absence of a unified immigration system on the EU level, significant progress has been made in harmonizing rules regarding admission and treatment of migrants. There is a clear trend in favouring skilled immigration (EU Blue Card Directive 2009/50/EC and Directive 2005/71/EC). These directives stipulate simplified visa and admission procedures for the respective categories and a fast track to permanent residence upon satisfaction of certain criteria. Legal long-term migrants have the right to bring in their families, obtain access to health care, education and public services (Directive 2003/86/EC, Directive 2003/109/EC) and there are common rules for admission of students (Directive 2004/114/EC). A significant achievement is the agreement on the single residence permit that stipulates the issue of a single document that encompasses the residence and work permit (Directive 2011/98/EU).

The external dimension of the EU immigration policy includes active cooperation with countries of origin and transit in terms of tighter border enforcement and control, cooperation on data sharing and readmission of undocumented migrants. The Global Approach to Migration set out in the Stockholm program for 2010-2014 calls for actions that ensure efficient management of migration flows to benefit all countries concerned. Three types of agreements with non-EU (third) countries are actively being used: mobility partnerships, readmission agreements and visa facilitation agreements.

\footnotetext{
${ }^{11}$ For detailed description see OECD (2013) for the EU, Mavroudi and Warren (2013) for the UK, Gera and Songsakul (2007) for Canada and Miller (1999) for Australia.
} 
The mobility partnerships aim at better management of immigration flows via development programs in the migrant source country and circular mobility programs. The intention here is to make a difference in the country of origin, before the person actually becomes a migrant. The projects implemented within each partnership depend on the needs of a particular country, though there is a preference to encourage legal temporary migration, better border control, data and information sharing to discourage potential undocumented migration. Mobility partnerships work on "more-for-more" principle, when more cooperative third countries get less restrictive visa regimes. As of the end of 2012 mobility partnerships were signed with four countries: Georgia, Moldova, Armenia and Cape Verde.

The readmission agreements are aimed at combatting illegal migration. They establish a procedure under which the source country accepts undocumented migrants who either originate from that country or used it as a transit country. Despite the fact that only half of the repatriated cases end up in readmission, Billet (2010) argues that the readmission agreements are a milestone in coordination of the immigration flows between the EU and large sending countries. In exchange for the cooperation on readmissions the EU may grant visa facilitation agreements that simplify visa requirements for seasonal and temporary migrants from cooperating third countries. The readmission and visa facilitation agreements have been signed with Moldova, Georgia, Ukraine and Russia, amongst other countries.

\section{The Model}

The world consists of two regions: North and South. North represents developed migrant receiving countries, for example OECD members, and South represents developing migrant sending countries, for example republics of the Former Soviet Union, India or Latin America. ${ }^{12}$ Country A is an average country of North and Country B is a large representative country of South. Migration statistics presented in Table 2 suggests division of the economies of both countries into migrant and non-migrant sectors. In Country A the

\footnotetext{
${ }^{12}$ See United Nations (2011) and Marchiori et al. (2013) for a more extensive definition of North and South.
} 
migrant sector employs native and migrant workers and can be though of as elementary, clerks and service occupation in manufacturing, trade or health care. The non-migrant sector employs only native workers. In Country B workers can emigrate only from the migrant sector. In either country assignment to sectors is exogenous and workers cannot switch sectors. Each worker inelastically supplies one unit of labor.

\subsection{The setup}

Country A produces the final good competitively with the Cobb-Douglas constant returns to scale technology:

$$
Y^{A}=Z^{A}\left(L^{A}\right)^{\beta}\left(H^{A}+M\right)^{1-\beta}
$$

where $Z^{A}$ is the total factor productivity, $H^{A}$ and $L^{A}$ is native labor employed in migrant and non-migrant sectors respectively, $M$ is migrant labor. Let $N^{A}$ be the total native population.

Under the assumption of competitive factor markets the wage in each sector equals the marginal product of its workers:

$$
\begin{aligned}
& w_{L}^{A}=\beta Z^{A}\left(L^{A}\right)^{\beta-1}\left(H^{A}+M\right)^{1-\beta}=\beta \frac{Y^{A}}{L^{A}} \\
& w_{H}^{A}=(1-\beta) Z^{A}\left(L^{A}\right)^{\beta}\left(H^{A}+M\right)^{-\beta}=(1-\beta) \frac{Y^{A}}{H^{A}+M} .
\end{aligned}
$$

The output is divided between the migrant and non-migrant sectors in shares $(1-\beta)$ and $\beta$.

Migrant workers come from a less developed Country B with total population $N^{B}$. Output in Country B is produced competitively according to the Cobb-Douglas technology with constant returns to scale:

$$
Y^{B}=Z^{B}\left(L^{B}\right)^{\gamma}\left(H^{B}-M\right)^{1-\gamma}
$$

where $H^{B}$ is labor employed in the migrant sector, $M$ are emigrants, $L^{B}$ are workers employed in the non-migrant sector who cannot emigrate.

Similarly, under the assumption of competitive factor markets the wages in Country 
B are:

$$
\begin{aligned}
& w_{L}^{B}=\gamma Z^{B}\left(L^{B}\right)^{\gamma-1}\left(H^{\beta}-M\right)^{1-\gamma}=\gamma \frac{Y^{B}}{L^{B}} \\
& w_{H}^{B}=(1-\gamma) Z^{B}\left(L^{\beta}\right)^{\gamma}\left(H^{\beta}-M\right)^{-\gamma}=(1-\gamma) \frac{Y^{B}}{H^{B}-M} .
\end{aligned}
$$

The output is divided between the migrant and non-migrant sectors in shares $(1-\gamma)$ and $\gamma$. To generate individual migration incentives I assume that Country A is technologically more advanced than Country B.

\subsection{Free migration}

Each worker employed in the migrant sector of Country B faces the choice whether to stay and get wage $w_{H}^{B}$ for the unit of labour supplied, or emigrate to Country A and get $w_{H}^{A}, w_{H}^{A}>w_{H}^{B}$. In order to emigrate worker $i$ must pay $c(i)$ for the migration costs. ${ }^{13}$ Worker's maximization problem is formalized as follows:

$$
\begin{array}{cl}
\max & \left\{w_{H}^{B}, w_{H}^{A}-c(i)\right\} \\
\text { s.t. } & \text { equations (2) and (4). }
\end{array}
$$

The worker emigrates if the wage gain exceeds or equals the individual migration costs and stays otherwise. The individual index $i$ ranks workers according to their migration costs; higher values of the index corresponds to higher costs, $i \in\left[0, H^{B}\right]$ (see Figure 2). Workers with low costs emigrate first. Worker with $i=0$ has zero migration costs and gains $w_{H}^{A}-w_{H}^{B}$ from emigration. The marginal worker's costs increase by $\frac{\bar{C}}{H^{B}}$ and worker $i$ gains $w_{H}^{A}-w_{H}^{B}-i \frac{\bar{C}}{H^{B}}$ from emigration. This is equivalent to saying that $c(i) \sim U[0, \bar{C}] .{ }^{14}$ Let $M^{M}$ denote the market level of emigration, which is determined from the following equations:

$$
\breve{w}_{H}^{A}-\breve{w}_{H}^{B}=M^{M} \frac{\bar{C}}{H^{B}}
$$

where $\breve{w}_{H}^{A}$ and $\breve{w}_{H}^{B}$ are wages at $M^{M}$.

\footnotetext{
${ }^{13}$ In broader migration literature the individual migration costs include material costs of the move, costs of social exclusion and discrimination. Carrington et al. (1996), Beine et al. (2011) find that the migration costs decline as the stock of migrants of the same nationality grows.

${ }^{14}$ The distribution assumption does not affect the model result, however makes it more trackable.
} 


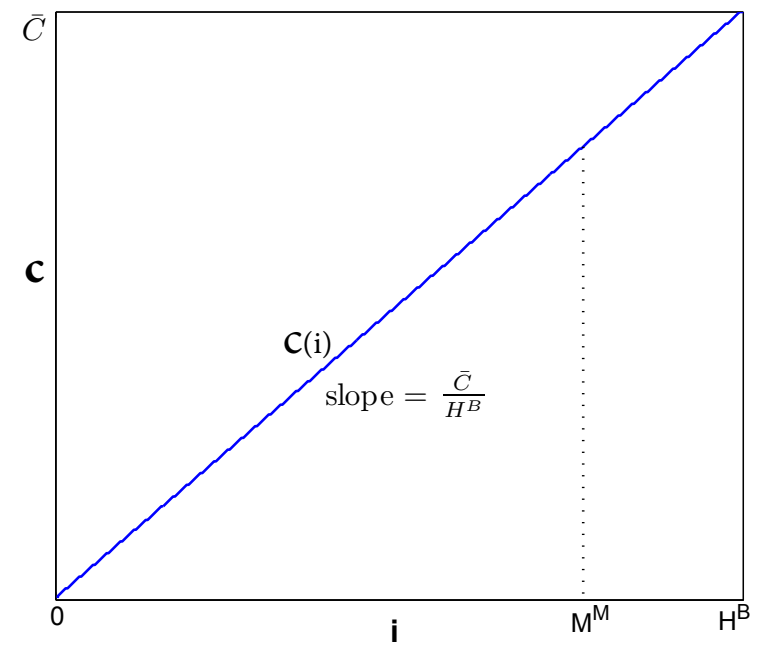

Figure 2: Visualization of individual migration costs.

Given the migration level $M^{M}$ and the assumption of the uniform distribution of the costs, the total migration costs paid, which is the area of triangular below the diagonal line in Figure 2, equal $\frac{\left(M^{M}\right)^{2} \bar{C}}{2 H^{B}}$.

If Country A becomes relatively more technologically developed, ceteris paribus, $M^{M}$ will increase. If Country A employs more people in the migrant sector, the wage in that sector declines thus reducing $M^{M}$. If $\bar{C}$ increases, the average migration costs increase, thus resulting in less migration. $M^{M}$ does not depend on the total population in both countries, however it does depend on the distribution of workers across the two sectors.

It must further be noted, that the individual decision rule in equation (5) accounts for the fact that in the migrant sector a moving worker decreases the wage in Country A and increases the wage in Country B. This however ignores a number of the welfare effects, for example, change in income of native and migrant workers induced by the change in wages (Card, 1990; Bratsberg and Raaum, 2012) as well as the social costs incurred from immigration (Giordani and Ruta, 2011). 


\subsection{Country A preference}

Country A maximizes the welfare of its native workers by choosing the volume of migrants $M$ to accept for employment in the migrant sector. The maximization problem is defined as follows:

$$
\begin{aligned}
\max _{\{M\}} W^{A}(M)= & L^{A} w_{L}^{A}+H^{A} w_{H}^{A}-\frac{A}{2}\left(\frac{M}{N^{A}}\right)^{2} N^{A} \\
\text { s.t. } \quad & \text { equations (1) and (2) } \\
& M \geq 0 .
\end{aligned}
$$

The first two terms of the welfare function is the income that accrues to the native workers minus wages paid to migrants. The third term is the social immigration costs incurred by the receiving country. ${ }^{15}$ This term expresses in monetary terms the value of all costs that the country incurs from accepting migrant workers: border controls and policing, integration and language courses or simply the natives' dissatisfaction from having migrants around.

The welfare effect of immigration is derived by differentiating (7) w.r.t. $M$. After rearrangement I obtain:

$$
\frac{\partial W^{A}}{\partial M}=L^{A} \frac{\partial w_{L}^{A}}{\partial M}+H^{A} \frac{\partial w_{H}^{A}}{\partial M}-\frac{A}{N^{A}} M=\frac{\beta w_{H}^{A}}{N^{A}}\left(1-\frac{H^{A}}{H^{A}+M}\right)-\frac{A}{N^{A}} M .
$$

Since $\frac{\beta w_{H}^{A}}{N^{A}}\left(1-\frac{H^{A}}{H^{A}+M}\right)>0$ for $M>0$, the natives' income is strictly increasing in the number of migrants. Disregarding the social costs, the native workers are strictly better off from the marginal migrant. To see why it is so, consider the migrant's effect on output:

$$
w_{H}^{A}=\frac{\partial Y^{A}}{\partial M}=\frac{\partial}{\partial M}\left(L^{A} w_{L}^{A}+\left(H^{A}+M\right) w_{H}^{A}\right)=L^{A} \frac{\partial w_{L}^{A}}{\partial M}+H^{A} \frac{\partial w_{H}^{A}}{\partial M}+M \frac{\partial w_{H}^{A}}{\partial M}+w_{H}^{A}
$$

A migrant is paid his marginal product and his arrival generates two more effects which cancel out: a positive effect on wage in the non-migrant sector and a negative

\footnotetext{
${ }^{15}$ Giordani and Ruta (2011) use s different functional form for the costs, but the function properties remain the same.
} 
effect on wage in the migrant sector.

$$
\underbrace{L^{A} \frac{\partial w_{L}^{A}}{\partial M}+H^{A} \frac{\partial w_{H}^{A}}{\partial M}}_{\text {effect on natives, }>0}+\underbrace{M \frac{\partial w_{H}^{A}}{\partial M}}_{\begin{array}{c}
\text { effect on } \\
\text { diaspora, } \leq 0
\end{array}}=0 .
$$

The negative effect on the wage in the migrant sector reduces the income of the native and migrant workers. Reduction of the natives' income is smaller in absolute value than the increase in the non-migrant sector. For this reason, disregarding the social costs, immigration always increases the natives' income. The positive effect on the locals is referred to in the literature as the "immigration surplus" (Borjas, 1995b; Giordani and Ruta, 2011).

The third term in equation (8) is the effect of migrants on their own income, which I call the diaspora effect. This effect is defined to be:

$$
M \frac{\partial w_{H}^{A}}{\partial M} \begin{cases}=0 & \text { if } M=0 \\ <0 & \text { if } M>0 .\end{cases}
$$

The diaspora effect does not affect the welfare of Country A, because the migrants take away the negative effect on themselves. The diaspora effect in a crucial way affects the welfare of Country B, which is considered in detail in Section 3.4.

It costs $\frac{A}{N^{A}}$ in social costs to accepts the marginal migrant. The welfare effect of immigration is:

$$
\frac{\partial W^{A}}{\partial M} \begin{cases}=0 & \text { if } M=0 \\ \geq 0 & \text { if } \frac{\beta w_{H}^{A}}{N^{A}}\left(1-\frac{H^{A}}{H^{A}+M}\right) \geq \frac{A}{N^{A}} M \\ <0 & \text { if } \frac{\beta w_{H}^{A}}{N^{A}}\left(1-\frac{H^{A}}{H^{A}+M}\right)<\frac{A}{N^{A}} M .\end{cases}
$$

When there are no migrants in Country A, $M=0$, the first migrant does not generate the diaspora effect, therefore the effect on the locals is zero. When migration continues, the marginal migrant positively affects the natives' income, and negatively affects the income of migrants already in the country through the diaspora effect. Country A will continue to accept migrants until the marginal increase in the natives' income equalizes with the marginal increase in the social costs. The last migrant allowed in increases the 
locals' income by strictly as much as he increases the social costs.

Denote the optimal volume of migrants that solves maximization problem (7) by $M^{A}$. Using the welfare effects as the sole determinant of the immigration policy, two immigration policy profiles of Country A are considered:

\section{Immigration quota:}

$$
M^{A}=\left[\frac{N^{A} Z^{A} \beta(1-\beta)\left(L^{A}\right)^{\beta}}{A}\right]^{\frac{1}{1+\beta}}-H^{A}
$$

\section{Immigration ban:}

$$
M^{A}=0 .
$$

The immigration quota defines the immigration volume that maximizes the welfare of Country A. It can happen that the quota is not exhausted, in which case the first-best outcome is not achieved. The country will not accept more than the quota, because of the social costs. The quota is strictly increasing in the total workforce, $N^{A}$, total factor productivity, $Z^{A}$, and decreasing in the social cost parameter $A$. When the native workforce is predominantly employed in the non-migrant sector, the country accepts many migrants, because the welfare can be increased by extending employment in the migrant sector. The immigration quota $M^{A}$ is concave in $\beta$. For low values of $\beta$ the migrant sector is more important in production and has a high marginal effect on the welfare. As $\beta$ increases the marginal effect on the quota is positive until a certain point, after which it becomes negative. For small and large values of $\beta$ the quota is smaller than for intermediate values.

When migrants do not cause any social costs, i.e. $A=0$, the country accepts infinitely many migrants, because the marginal effect on the natives' income is strictly positive, as derived in equation (8). Similar "open door" immigration policy predictions are confirmed by Bianchi (2013) and Giordani and Ruta (2011). 


\subsection{Country B preference}

Migrant workers come to Country A from a less developed Country B. If Country B could choose how many emigrants to send, it would do so by maximizing the welfare of its emigrants and stayers. It thus solves the following maximization problem:

$$
\begin{aligned}
& \max _{\{M\}} W^{B}(M)= M w_{H}^{A}-M \frac{M \bar{C}}{2 H^{B}}+L^{B} w_{L}^{B}+\left(H^{B}-M\right) w_{H}^{B} \\
& \text { s.t. } \quad \text { equations }(1),(2),(3) \text { and }(4) \\
& M \geq 0 .
\end{aligned}
$$

The first term of the welfare function is the income of migrants, the second term is the total individual migration costs, the third and fourth terms are the income of stayers in Country B. To learn the welfare effects of emigration I have to differentiate (10) w.r.t. $M$. After rearrangement I obtain:

$$
\frac{\partial W^{B}}{\partial M}=\underbrace{w_{H}^{A}-w_{H}^{B}-\frac{M \bar{C}}{H^{B}}}_{\begin{array}{c}
\text { net gain from } \\
\text { emigration }
\end{array}}+\underbrace{M \frac{\partial w_{H}^{A}}{\partial M}}_{\begin{array}{c}
\text { diaspora } \\
\text { effect, } \leq 0
\end{array}}+\underbrace{L^{B} \frac{\partial w_{L}^{B}}{\partial M}+\left(H^{B}-M\right) \frac{\partial w_{H}^{B}}{\partial M}}_{\text {effect on stayers, }=0} .
$$

Starting from no emigration, $M=0$, the first migrant gains $w_{H}^{A}$, looses $w_{H}^{B}$ and pays nothing in migration costs. For the first migrant, the diaspora effect is zero, because no migrants in Country A are affected by the wage reduction. For $M>0$ each marginal migrant will reduce the wage paid to the first migrant, thus generating the negative diaspora effect.

Emigration has two effects on stayers; increase of wage in the migrant sector and decrease of wage in the non-migrant sector. These two effects cancel out:

$$
-w_{H}^{B}=\frac{\partial Y^{B}}{\partial M}=\frac{\partial}{\partial M}\left(L^{B} w_{L}^{B}+\left(H^{B}-M\right) w_{H}^{B}\right)=L^{B} \frac{\partial w_{L}^{B}}{\partial M}+\left(H^{B}-M\right) \frac{\partial w_{H}^{B}}{\partial M}-w_{H}^{B}
$$


The welfare effect of emigration on Country B is thus:

$$
\frac{\partial W^{B}}{\partial M}\left\{\begin{array}{l}
=w_{H}^{A}-w_{H}^{B} \text { if } M=0 \\
\geq 0 \text { if } w_{H}^{A}-w_{H}^{B} \geq \frac{M \bar{C}}{H^{B}}-M \frac{\partial w_{H}^{A}}{\partial M} \text { and } M>0 \\
<0 \text { if } w_{H}^{A}-w_{H}^{B}<\frac{M \bar{C}}{H^{B}}-M \frac{\partial w_{H}^{A}}{\partial M} \text { and } M>0
\end{array}\right.
$$

The first migrant increases welfare by exactly as much as his net private gain from emigration. From then on, each marginal migrant increases the welfare by less than the private gain from emigration because of the negative diaspora effect. As the number of migrants increases, the marginal welfare gain declines, because the wage differential narrows, the individual migration costs increase and the diaspora effect grows. The country prefers to send migrants as long as the wage differential exceeds the marginal migration costs and the marginal decline in income of the diaspora. The wage gain for the last migrant that Country B wants to send exactly equals the marginal migration costs plus the marginal increase in the diaspora effect.

I use $M^{B}$ to denote the emigration level that solves maximization problem (10) and $\widehat{w}_{H}^{A}, \widehat{w}_{H}^{B}$ to denote wages at $M^{B}$. Two emigration profiles of Country B are considered:

\section{Emigration quota:}

$$
\widehat{w}_{H}^{A}-\widehat{w}_{H}^{B}=\frac{M^{B} \bar{C}}{H^{B}}+M^{B} \frac{\beta \widehat{w}_{H}^{A}}{H^{A}+M^{B}}
$$

\section{Emigration ban:}

$$
M^{B}=0
$$

Comparing equations (12) and (6) one can notice that they differ only by the term that captures the diaspora effect. This means that for $M>0$ Country B always prefers to have fewer migrants than the volume that self-establishes under free migration.

The emigration quota depends on the sectoral distribution of workers. Larger employment in the migrant sector in County A (B) will reduce (increases) the wage differential, thus driving down (up) the emigration quota. If $Z^{A}\left(Z^{B}\right)$ increases, $M^{B}$ will increase (decrease), because the difference in wages rises (falls). If the average migration costs decline, i.e. $\bar{C}$ falls, Country B prefers to have more migrants. 


\subsection{Political union preference}

Suppose that the two countries form a political union. It is then interesting to know how many migrants the union would like to have. The union solves the following maximization problem:

$$
\begin{aligned}
\max _{\{M\}} W^{U}(M)= & L^{A} w_{L}^{A}+H^{A} w_{H}^{A}-\frac{A}{2}\left(\frac{M}{N^{A}}\right)^{2} N^{A}+M w_{H}^{A}-M \frac{M \bar{C}}{2 H^{B}}+ \\
+ & L^{B} w_{L}^{B}+\left(H^{B}-M\right) w_{H}^{B} \\
\text { s.t. } \quad & \text { equations (1), (2), (3) and (4) } \\
& M \geq 0 .
\end{aligned}
$$

The first three terms of the objective function is the income that accrues to the natives of Country A, net wages paid to migrants and the social immigration costs. The fourth and fifth terms are the migrants' income minus the migration costs. The second line is the income of stayers in Country B.

To learn the welfare effects of migration I have to differentiate (13) w.r.t. M. After rearrangement I obtain:

$$
\begin{aligned}
\frac{\partial W^{U}}{\partial M}=\underbrace{L^{A} \frac{\partial w_{L}^{A}}{\partial M}+H^{A} \frac{\partial w_{H}^{A}}{\partial M}+M \frac{\partial w_{H}^{A}}{\partial M}}_{=0}+\underbrace{w_{H}^{A}-w_{H}^{B}-M \frac{A}{N^{A}}}_{\begin{array}{c}
\text { net gain from } \\
\text { emigration }
\end{array}}-\underbrace{M \frac{\bar{C}}{H^{B}}}_{\begin{array}{c}
\text { social } \\
\text { cost }
\end{array}}+ \\
+\underbrace{L^{B} \frac{\partial w_{L}^{B}}{\partial M}+H^{B} \frac{\partial w_{H}^{B}}{\partial M}-M \frac{\partial w_{H}^{B}}{\partial M}}_{\text {effect on stayers' income, }=0} .
\end{aligned}
$$

The marginal migrant with index $i$ gains $w_{H}^{A}$, looses $w_{H}^{B}$ and pays $i \frac{\bar{C}_{H}}{H^{B}}$ for the immigration costs. For accepting this migrant the union pays $\frac{A}{N^{A}}$ in the form of social costs. The marginal net gain to the union is thus $w_{H}^{A}-w_{H}^{B}-i \frac{\bar{C}_{H}}{H^{B}}-\frac{A}{N^{A}}$. Since the union cares about the welfare of all its workers irrespective of their country profile, migrants stop being migrants and the pronounced diaspora effect is internalized as it is shown in equation (8).

The union prefers to have migrants as long as the wage gain from migration exceeds the marginal individual and social costs. For the last migrant the wage gain will exactly 
equal the marginal individual and social costs. The welfare effect of migration in the union is as follows:

$$
\frac{\partial W^{U}}{\partial M}\left\{\begin{array}{l}
=w_{H}^{A}-w_{H}^{B}-\frac{A}{N^{A}} \text { if } M=0 \\
\geq 0 \text { if } w_{H}^{A}-w_{H}^{B} \geq \frac{M \bar{C}}{H^{B}}+\frac{A}{N^{A}} M \text { and } M>0 \\
<0 \text { if } w_{H}^{A}-w_{H}^{B}<\frac{M \bar{C}}{H^{B}}+\frac{A}{N^{A}} M \text { and } M>0 .
\end{array}\right.
$$

Let $M^{U}$ denote the optimal migration level within the union, $\bar{w}_{H}^{A}$ and $\bar{w}_{H}^{B}$ denote wages at $M^{U}$. Then two migration profiles of the union are considered:

\section{Migration quota:}

$$
\bar{w}_{H}^{A}-\bar{w}_{H}^{B}=\frac{M^{U} \bar{C}_{H}}{H^{B}}+\frac{A}{N^{A}} M^{U}
$$

\section{Migration ban:}

$$
M^{U}=0
$$

The union migration policy is the weighted average of the individual migration profiles of the two countries. If Country A accepts migrants more aggressively than Country B wishes to send them, the optimal volume for the union will be below that of Country A and above than of Country B. In the opposite case, when Country A wishes to accepts less migrants than Country B wants to send, the union preference will be above that of Country A and below that of Country B.

When the social costs of immigration are reduced to zero, $A=0$, the union preference equals the free market outcome, because the migrants in the union do not impose any negative effects on the income of other migrants. This intuition is formalized in Proposition 1. 


\subsection{Comparison of outcomes}

In this section I compare the four migration outcomes: free market, preference of Country A, preference of Country B and preference of the political union. As a starting point, let me recall the optimal migration levels:

$$
\begin{aligned}
\text { Market: } & \breve{w}_{H}^{A}-\breve{w}_{H}^{B}=\frac{M^{M} \bar{C}}{H^{B}} \\
\text { Country A: } & \beta \widetilde{w}_{H}^{A}\left(1-\frac{H^{A}}{H^{A}+M^{A}}\right)=\frac{A M^{A}}{N^{A}} \\
\text { Country B: } & \widehat{w}_{H}^{A}\left(1-\frac{\beta M^{B}}{H^{A}+M^{B}}\right)-\widehat{w}_{H}^{B}=\frac{M^{B} \bar{C}}{H^{B}} \\
\text { Union: } & \bar{w}_{H}^{A}-\bar{w}_{H}^{B}=\frac{M^{U} \bar{C}}{H^{B}}+\frac{A M^{U}}{N^{A}}
\end{aligned}
$$

where $\breve{w}_{H}^{S}, \widetilde{w}_{H}^{S}, \widehat{w}_{H}^{S}$ and $\bar{w}_{H}^{S}, S=A, B$, are wages in migrant sectors at respective migration levels. The four outcomes are depicted in Figure 3.

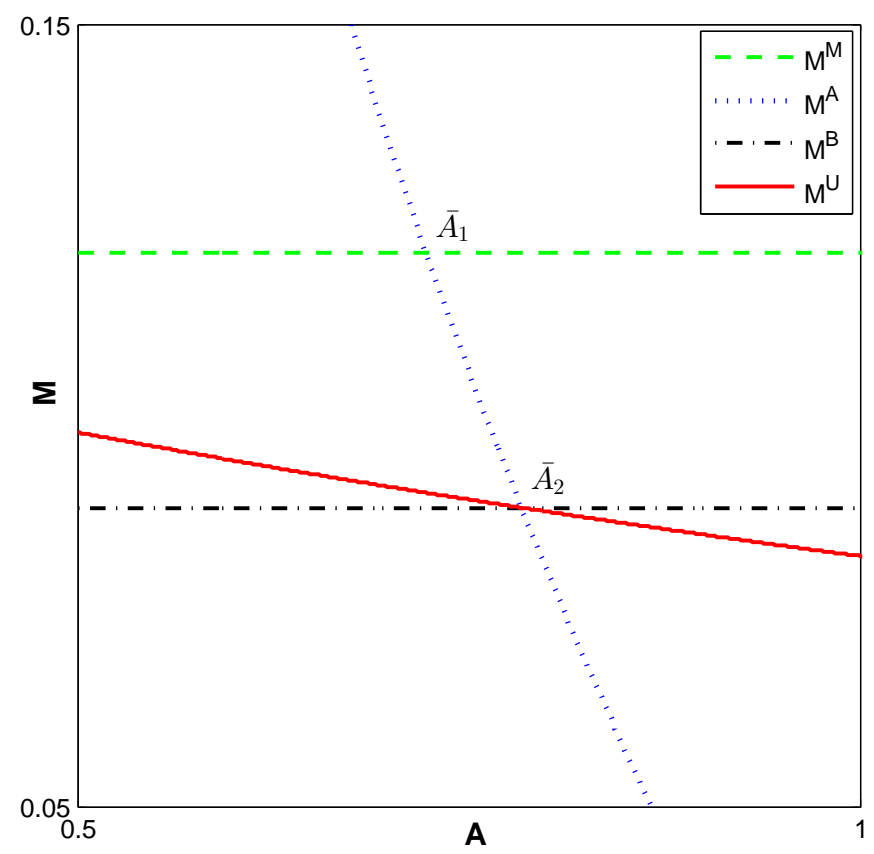

Figure 3: Illustration of the migration outcomes for the following parameter values: $Z^{A}=2, Z^{A}=1.5, N^{A}=N^{B}=1, H^{A}=H^{B}=0.5, \beta=\gamma=0.5, \bar{C}=0.15$.

The immigration quota $M^{A}$ defines the volume of immigrants that is best for the receiving Country A. When the social immigration cost parameter $A$ declines, the country accepts more migrants. 
The market outcome defines a migration level when workers are allowed to move freely. The worker's decision to move, as given by maximization problem (5), weights the wage differential against the marginal migration costs. It ignores the social immigration costs and the negative effect of migrants on their own income through the diaspora effect.

The preference of County B defines the volume of migrants that is best for its welfare, which consists of the income of workers in the non-migrant sector, stayers in the migrant sector and the emigrants. When the wage differential is sufficiently high, Country B can increase its welfare by expatriating some of its workers to work in Country A where they are more productive. As the number of emigrants increases, the wage in the destination country falls, thus decreasing the income of migrants (diaspora effect). The optimal emigration quota for Country B is when the wage differential equals the marginal decrease in the migrants' income plus the marginal migration costs. This compares to the market migration level, which disregards migrants' effect on their own income. Proposition 1 shows that the negative diaspora effect decreases the optimal volume of migrants for the source country relative to the free market level.

The union outcome describes the case when both countries can agree on such a level of migration, which is best for the world. The union quota is thus a weighted average of the preferences of sending and receiving countries; it accounts for the wage differential, social and individual costs as well as the negative diaspora effect. Since in the union migrant workers stop being migrants (their well-being is cared for by the planner) the negative diaspora effect is internalized. For this reason Country B always benefits from coordination.

Two propositions below rank the migration outcomes depending on the value of the social cost parameter. 
Proposition 1. If $A=0$, the outcomes are ranked $M^{A}>M^{M}=M^{U}>M^{B}$.

Proof. If $A=0$, then from equations (9) or (16) it follows that $M^{A} \rightarrow \infty$. Next, $M^{M}=M^{U}$ because equations (15) and (18) are the same. Further, I subtract equation (15) from (17) to obtain:

$$
\widehat{w}_{H}^{A}\left(1-\frac{\beta M^{B}}{H^{A}+M^{B}}\right)-\breve{w}_{H}^{A}+\breve{w}_{H}^{B}-\widehat{w}_{H}^{B}=\frac{\bar{C}}{H^{B}}\left(M^{B}-M^{M}\right)
$$

If $M^{B}>M^{M}$, then the LHS of (19) is negative but the RHS is positive, which is a contradiction. If $M^{B}=M^{U}$, then the LHS is negative but the RHS $=0$, which is again a contradiction. Then $M^{B}<M^{M}$ is the true relationship, because it does not produce a contradiction.

By the transitivity property the ranking $M^{A}>M^{M}=M^{U}>M^{B}$ follows.

Proposition 1 establishes the first key result of the paper - over-emigration. If workers are allowed to move freely, the market outcome delivers more migrants than the quota of Country B, $M^{M}>M^{B}$. In other words, more people move than is optimal for the source country. Compared to findings of the brain drain literature, this result suggests that emigration of a marginal worker decreases output in the sending country by the worker's wage; emigration does not decrease the income of stayers; and, finally, the emigration of $M^{M}-M^{B}$ extra migrants is harmful to the source country, because they excessively decrease the income of $M^{M}$ migrants who are already in the destination country.

Further, since the union preference internalizes the negative diaspora effect and when the social immigration costs are zero, the union quota equals the free market level of migration. The political union prefers to have as many migrants as workers who wish to move. This result also follows from the application of the First Welfare Theorem. In the absence of social immigration costs the receiving country prefers the open door immigration policy, because the marginal benefit of an additional migrant is strictly positive. This result is not uncommon in the literature; Giordani and Ruta (2011) and Bianchi (2013) are most recent studies that confirm it. 
Proposition 2. There exist $\overline{A_{1}}$ and $\overline{A_{2}}$, such that:

$$
\begin{array}{lll}
M^{A}>M^{M}>M^{U}>M^{B} & \text { if } & A<\overline{A_{1}} \\
M^{M}>M^{A}>M^{U}>M^{B} & \text { if } & \overline{A_{1}}<A<\overline{A_{2}} \\
M^{M}>M^{B}>M^{U}>M^{A} & \text { if } & A>\overline{A_{2}} .
\end{array}
$$

Proof. The three cases are depicted in Figure 3. It follows from Proposition 1 that $M^{M}$ and $M^{A}$ do not depend on $A$, they are parallel lines with $M^{M}$ above $M^{B}, \frac{\partial M^{M}}{\partial A}=\frac{\partial M^{B}}{\partial A}=$ $0, M^{M}>M^{B}$.

$M^{A}$ is a continuous function decreasing in $A$. For small values of $A M^{A}$ is above $M^{M}$ and for large values $M^{A}$ is below $M^{B}$. There exist a unique point $\overline{A_{1}}$ at which $M^{A}$ intersects $M^{M}$, such that if $A<\overline{A_{1}}, M^{A}>M^{M}$, and conversely, if $A>\overline{A_{1}}, M^{A}<M^{M}$. Similarly, there exist a unique point $\overline{A_{2}}$ at which $M^{A}$ intersects $M^{B}$, such that if $A<\overline{A_{2}}$, $M^{A}>M^{B}$, and, conversely, if $A>\overline{A_{2}}, M^{A}<M^{B}$. Since $M^{A}$ is a downward sloping line, it first crosses $M^{M}$ and then $M^{B}, \overline{A_{1}}<\overline{A_{2}}$.

$M^{U}$ is a continuous function decreasing in $A$. For $A=0 M^{U}=M^{M}$ (Proposition 1), and for $A>0 M^{U}<M^{M}$. For small values of $A M^{U}>M^{B}$, and for large values $M^{U}<M^{B}$. There exists a point at which $M^{U}$ crosses $M^{B}$ and this point is unique. If I add equations (16) and (17) I get equation (18), which implies that $M^{A}, M^{U}$ and $M^{B}$ intersect in one point, $\overline{A_{2}}$. If $A<\overline{A_{2}}, M^{U}$ lies below $M^{A}$ but above $M^{B}, M^{A}>M^{U}>$ $M^{B}$, and conversely, if $A>\bar{A}_{2}, M^{B}>M^{U}>M^{A}$.

Conditions (20)-(22) are depicted in Figure 3. Condition (20) describes the case when due to low social immigration costs the immigration quota is set high enough and it exceeds three other outcomes. In this case the quota will not be exhausted, because less migrants wish to move under the free migration.

When condition (21) holds the social cost parameter is high enough and brings the immigration quota below the market level. This establishes the second key result of the paper. Given the finding of over-emigration, enforcement of the immigration quota by the host country benefits the welfare of the source country, because it reduces the volume of excessive migrants from $M^{M}-M^{B}$ to $M^{A}-M^{B}$, thus reducing the negative diaspora effect. Contrary to the well-acknowledged opinion, that developed countries should accept 
more migrants to increase the welfare in the developing source region, if condition (21) holds, enforcement of the quota actually benefits the source country.

If condition (22) holds, the social immigration costs are too high and the immigration quota is set too low. If the quota is enforced, there will be rationing of migrants and under-emigration with respect to what is best for the source country, the union and the market.

\subsection{Comparison with brain drain}

The brain drain literature finds that emigration of skilled workers decreases the welfare of those left behind and reduces economic growth in sending countries (Bhagwati and Hamada, 1974; Bhagwati and Hamada, 1982; Dustmann et al., 2011; Mountford and Rapoport, 2011). In comparison this result establishes that if the welfare of the willbe migrants while they are in Country B is accounted for, the effect on stayers is zero. However, if the will-be migrants are excluded from the welfare, then for given $M$ the marginal effect on stayers is negative.

The marginal effect of emigration on stayers and will-be migrants from equation (11) is:

$$
L^{B} \frac{\partial w_{L}^{B}}{\partial m}+\left(H^{B}-m\right) \frac{\partial w_{H}^{B}}{\partial m}=0
$$

The total effect is also zero:

$$
\int_{0}^{M} L^{B} \frac{\partial w_{L}^{B}}{\partial m}+\left(H^{B}-m\right) \frac{\partial w_{H}^{B}}{\partial m} d m=0
$$

Suppose now that a social planner knows $M$ in advance and wishes to compute the welfare effect on stayers excluding the will-be migrants while they are still in Country B. The marginal effect is then:

$$
L^{B} \frac{\partial w_{L}^{B}}{\partial m}+\left(H^{B}-M\right) \frac{\partial w_{H}^{B}}{\partial m}<0 \text { for } M>m
$$

For $M>m$ the marginal effect in equation (25) is negative, and for $M=m$ it is zero. 
The total effect is therefore negative and given by:

$$
\int_{0}^{M} L^{B} \frac{\partial w_{L}^{B}}{\partial m}+\left(H^{B}-M\right) \frac{\partial w_{H}^{B}}{\partial m} d m<0
$$

Unlike the brain drain literature, the non-positive effect on the welfare of stayers holds for emigration of workers of any skill level and from any migrant sector of Country B: medical professionals, construction workers, computer scientists or cleaners.

\section{Conclusions}

In this paper I analyze the welfare effects of migration for three parties involved: migrants, receiving country and sending country. As stated in many studies, workers move in response to the wage differential between countries after deducing individual migration costs. Thus, when deciding to move, individual workers disregard their effect on the host and source countries' welfare as well as other migrants. The free migration level confronts the immigration quota of the receiving country; all prospective migrants move as long as the market level is below the quota, and the prospective migrants are rationed when the quota is below the market level.

In the absence of social immigration costs, immigration strictly benefits the receiving country. When these costs are not zero, the immigration quota is determined when the marginal increase in the host country workers' income equals the marginal increase in the social costs.

For the source country, emigration is found to decrease the output by the worker's wage. This however does not affect the income of stayers. I find that there is always overemigration with respect to what is optimal for the source country, because the individual decision rule does not account for the migrants' effect on their own income (diaspora effect), which is negative since migrants cluster in the same employment sector. Overemigration is harmful to the source country welfare. Under certain conditions the negative impact of over-emigration can be reduced when the destination country enforces the quota.

The source country prefers to coordinate the immigration quota with the host country, 
because in the coordinated outcome of the political union the migrant workers stop being migrants and the negative diaspora effect is internalized. When the social immigration costs are zero, the union quota delivers the same outcome as the free market. 
Appendix

Table 1: Standardized migration statistics.

\begin{tabular}{|c|c|c|c|c|c|c|c|c|c|c|c|c|c|c|c|c|c|c|c|c|}
\hline & 具 & 鳬 & 정 & 営 & 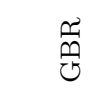 & 䒚 & 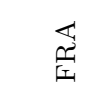 & $\begin{array}{l}\overleftrightarrow{L} \\
0 \\
D\end{array}$ & 国 & 坌 & $\underset{\mathscr{C}}{\mathscr{C}}$ & 崩 & 宸 & $\underline{\underline{\vartheta}}$ & 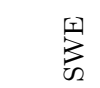 & 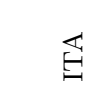 & 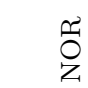 & 完 & $\stackrel{\vec{n}}{\vec{n}}$ & 急 \\
\hline & \multicolumn{20}{|c|}{ Permanent inflows and outflows in 2010 , per one thousand of local population* } \\
\hline Inflows & 11.7 & 10.4 & 2.9 & 2.4 & 8.1 & 3.4 & 2.2 & 3.4 & 17.2 & 8.4 & 2 & 31.5 & 6 & 3.9 & 8.4 & 7.1 & 13.3 & 6.6 & 2.8 & 9.4 \\
\hline Outflows & 7.9 & & 1.4 & 0.6 & 3.3 & 0.6 & . & & 8.4 & 8.2 & 4.2 & 15.2 & 4.9 & 8.4 & 2.4 & 0.5 & 4.6 & 2.4 & & 7.3 \\
\hline & \multicolumn{20}{|c|}{ Inflows in 2011 by category of entry, $\%$} \\
\hline Work & 1.4 & 18.3 & . & . & 33.1 & 5.8 & 11.9 & 6.4 & 2.1 & 9.0 & . & . & 19.6 & 16.3 & 5.7 & 40.5 & 5.1 & 10.9 & 21.9 & 29.9 \\
\hline Free movements & 63.7 & 39.6 & . & . & 17.4 & 39.0 & 30.3 & 0.0 & 71.4 & 59.9 & . & . & 50.9 & 71.8 & 35.9 & 28.2 & 67.4 & 56.9 & 36.3 & 49.9 \\
\hline Accompanying family & 0.9 & 0.0 & . & . & 14.6 & 0.0 & 0.0 & 7.8 & 0.0 & 0.0 & . & . & 5.9 & 4.0 & 0.0 & 1.2 & 0.0 & 0.0 & 0.0 & 0.0 \\
\hline Family & 23.2 & 36.2 & . & . & 11.8 & 34.3 & 42.9 & 66.3 & 18.8 & 24.7 & . & 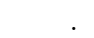 & 12.3 & 7.0 & 39.6 & 27.4 & 18.0 & 21.7 & 35.3 & 18.7 \\
\hline Humanitarian & 10.3 & 5.9 & . & . & 1.2 & 17.4 & 5.4 & 13.1 & 5.8 & 5.3 & . & . & 5.1 & 0.9 & 18.7 & 1.3 & 9.5 & 10.5 & 0.1 & 0.2 \\
\hline Other & 0.5 & 0.0 & . & . & 21.9 & 3.6 & 9.6 & 6.4 & 2.0 & 1.1 & & & 6.2 & 0.0 & 0.0 & 1.5 & 0.0 & 0.0 & 6.3 & 1.2 \\
\hline & \multicolumn{20}{|c|}{ Stock of migrants in $2010, \%$ of population } \\
\hline Foreign-born & 15.7 & 13.9 & 6.3 & 4.5 & 11.5 & 4.6 & 8.6 & 12.2 & 26.6 & 13 & 10.9 & 37.6 & 7.7 & 17.3 & 14.8 & 8 & 11.6 & 11.2 & & 14.5 \\
\hline Foreign nationals & \multirow{2}{*}{\multicolumn{20}{|c|}{$\begin{array}{ll}22.1 & 8.3 \\
\text { Unemployment rate in } 2011, \%\end{array}$}} \\
\hline & & & & & & & & & & & & & & & & & & & & \\
\hline Native-born & 3.4 & 5.8 & 6.8 & 11.1 & 8 & 7.6 & 8.5 & 9.2 & 3.1 & 5.4 & 17.4 & 3.4 & 6.9 & 14.1 & 6 & 8 & 2.7 & 3.8 & 13 & 19.5 \\
\hline Foreign-born & 8.2 & 15.1 & 8 & 9.5 & 9.4 & 15.2 & 15.1 & 9.1 & 6.8 & 9.5 & 22.2 & 6.3 & 14.5 & 17.3 & 16 & 11.7 & 7.7 & 9.2 & 16.9 & 31.5 \\
\hline $\begin{array}{l}\text { Share of foreign-born } \\
\text { in tot. empl., \%, } 2010\end{array}$ & 16.5 & 13.0 & 2.8 & 2.1 & 13.3 & 3.8 & 11.1 & 15.8 & 27.2 & 14.3 & 11.5 & 48.7 & 9.4 & 17.2 & 14.4 & 11.8 & 9.5 & 11.3 & 9.1 & 17.0 \\
\hline & \multicolumn{20}{|c|}{ Difference in education level shares: recent migrants $(2000-2010)$ minus young resident workers** } \\
\hline Low & 16.4 & 18.0 & 6.9 & 2.3 & 14.1 & 29.4 & 23.9 & 26.4 & 11.8 & 17.7 & 41.9 & 1.0 & & 9.0 & 20.7 & 28.9 & 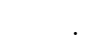 & 17.6 & 11.1 & 13.3 \\
\hline Medium & -21.2 & -7.3 & -4.2 & -8.6 & 6.1 & -6.6 & -12.4 & -12.0 & -22.0 & -31.2 & -8.8 & -26.5 & & 3.8 & -28.8 & -12.0 & & -10.1 & 8.9 & 13.3 \\
\hline High & 4.7 & -10.7 & -2.8 & 6.4 & -20.2 & -22.8 & -11.6 & -14.4 & 10.1 & 13.5 & -33.1 & 25.4 & -11.8 & -12.8 & 8.1 & -17.0 & -11.5 & -7.5 & -20.0 & -26.6 \\
\hline
\end{tabular}

Source: author's illustration using data from OECD (2011) and OECD (2012).

* National definitions of migrant.

** "Low" refers to less than upper secondary attainment, "medium" to upper secondary and post-secondary non-tertiary, "high" to tertiary.

A dot means that the data are unavailable or the estimate is unreliable. 
Table 2: Migrants' employment by sector and occupation group.

\begin{tabular}{|c|c|c|c|c|c|c|c|c|c|c|c|c|c|c|c|c|c|c|c|c|}
\hline & 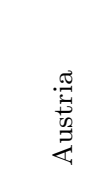 & 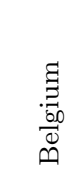 & 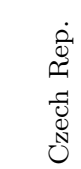 & 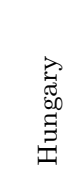 & 菅 & 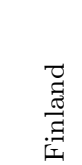 & 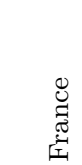 & $\stackrel{2}{\rho}$ & 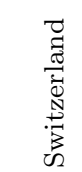 & 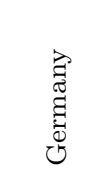 & 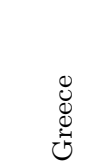 & 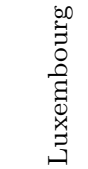 & 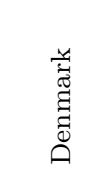 & 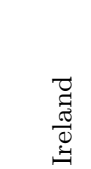 & 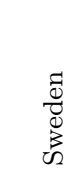 & $\stackrel{\vec{\Phi}}{\vec{\Phi}}$ & 空 & 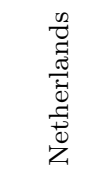 & $\begin{array}{l}\vec{Z}_{0} \\
0 \\
\underbrace{0}_{0} \\
0 \\
0\end{array}$ & $\begin{array}{l}\text { : } \\
\text { की } \\
\text { की }\end{array}$ \\
\hline & \multicolumn{20}{|c|}{ Distribution of migrants across employment sectors in $2011^{*}, \%$} \\
\hline Agriculture and fishing & 0.9 & 0.6 & 1.2 & & 0.5 & 2.6 & 1.3 & 2.2 & 1.2 & 0.7 & 8.9 & . & 2.4 & 2.2 & 0.6 & 4.0 & & 1.7 & . & 5.7 \\
\hline $\begin{array}{l}\text { Mining, manufacturing } \\
\text { and energy }\end{array}$ & 17.8 & 13.3 & 31.1 & 23.9 & 10.6 & 15.3 & 11.7 & 12.9 & 18.4 & 25.6 & 13.4 & 6.8 & 13.9 & 17.1 & 13.2 & 20.6 & 12.0 & 14.5 & 14.1 & 9.3 \\
\hline Construction & 11.8 & $\begin{array}{r}10.0 \\
9.6\end{array}$ & 10.1 & $\begin{array}{r}2.9 \\
7.9\end{array}$ & $\begin{array}{r}1.0 \\
5.7\end{array}$ & $\begin{array}{r}10.0 \\
6.1\end{array}$ & 12.3 & $\begin{array}{r}12.9 \\
9.3\end{array}$ & $\begin{array}{r}10.4 \\
8.0\end{array}$ & $\begin{array}{r}20.0 \\
7.0\end{array}$ & $\begin{array}{l}10.4 \\
19.2\end{array}$ & $\begin{array}{l}0.0 \\
9.9\end{array}$ & $\begin{array}{r}10.9 \\
1.8\end{array}$ & 4.2 & $\begin{array}{r}10.2 \\
4.1\end{array}$ & 13.6 & $\begin{array}{r}1.0 \\
6.2\end{array}$ & $\begin{array}{r}14.0 \\
4.2\end{array}$ & $\begin{array}{r}14.1 \\
9.9\end{array}$ & 10.5 \\
\hline Wholesale and retail trade & 14.6 & 11.8 & 15.1 & 16.1 & 13.2 & 12.8 & 11.7 & 13.9 & 14.2 & 12.7 & 14.6 & 10.8 & 11.8 & 16.3 & 11.1 & 10.1 & 11.2 & 12.6 & 13.3 & 13.6 \\
\hline Hotels and restaurants & 12.1 & 8.2 & 5.6 & 5.7 & 9.2 & 8.5 & 7.0 & 10.5 & 7.7 & 8.8 & 12.1 & 5.9 & 7.5 & 11.7 & 7.2 & 8.8 & 6.8 & 6.8 & 10.5 & 16.1 \\
\hline Education & 4.3 & 5.5 & 5.2 & 9.8 & 8.2 & 8.1 & 5.2 & 5.8 & 5.3 & 4.5 & 1.5 & 4.1 & 9.5 & 4.9 & 11.3 & 1.9 & 6.5 & 6.6 & 9.1 & 2.2 \\
\hline Health & 9.5 & 10.9 & 4.6 & 9.4 & 15.6 & 11.7 & 11.6 & 12.1 & 13.1 & 10.7 & 3.2 & 7.4 & 21.5 & 14.4 & 19.3 & 4.8 & 24.3 & 16.4 & 7.2 & 5.0 \\
\hline Households & & 2.2 & & & 0.4 & & 5.4 & 1.4 & 1.3 & 1.1 & 14.7 & 3.5 & & 1.0 & & 17.0 & & & 5.1 & 14.9 \\
\hline Administrative & 2.6 & 9.9 & 3.1 & 4.5 & 4.1 & 2.5 & 6.4 & 2.4 & 2.2 & 2.4 & 0.9 & 14.4 & 3.2 & 2.2 & 3.7 & 1.4 & 3.0 & 6.3 & 7.1 & 2.0 \\
\hline \multirow[t]{2}{*}{ Other services } & 25.8 & 28.0 & 23.9 & 20.1 & 32.4 & 32.3 & 27.5 & 29.5 & 28.6 & 26.6 & 11.5 & 37.0 & 28.0 & 26.0 & 29.4 & 17.7 & 28.5 & 30.8 & 22.2 & 20.6 \\
\hline & \multicolumn{20}{|c|}{ Difference in occupation shares: recent migrants (2000-2010) minus young resident workers } \\
\hline Elementary occupations & 17.1 & 11.4 & 9.4 & 1.8 & 10.6 & 17.9 & 15.2 & 14.6 & 4.7 & 14.3 & 38.7 & 3.1 & 19.2 & 17.7 & 12.5 & 34.2 & 14.2 & 16.2 & 24.6 & 34.0 \\
\hline $\begin{array}{l}\text { Clerks, service workers, skilled } \\
\text { trades, machinery operators } \\
\text { Professionals, senior }\end{array}$ & -1.2 & -1.7 & 5.4 & -4.2 & 3.3 & 0.6 & 3.0 & 1.7 & -5.3 & 2.6 & 0.8 & -7.4 & 3.8 & 18.5 & -1.4 & -1.0 & 5.8 & 7.4 & 5.5 & 2.9 \\
\hline $\begin{array}{l}\text { officials and managers } \\
\text { Technicians and }\end{array}$ & 1.9 & -5.6 & -0.8 & 11.7 & -7.5 & -6.0 & -2.9 & -16.3 & 11.9 & -2.4 & -25.4 & 14.3 & -8.6 & -28.8 & -1.1 & -9.3 & -3.8 & -13.8 & -18.3 & -20.3 \\
\hline associate professionals & -17.8 & -4.1 & -14.1 & -9.3 & -6.5 & -12.6 & -15.3 & 0.0 & -11.3 & -14.5 & -14.1 & -10.0 & -14.4 & -7.4 & -9.9 & -23.9 & -16.3 & -9.7 & -11.8 & -16.5 \\
\hline
\end{tabular}

Source: author's illustration using data from OECD (2012).

* ISIC classification, rev.3.

A dot means that the data are unavailable or the estimate is unreliable. 


\section{References}

Akin, S., 2012. Immigration, fiscal policy, and welfare in an aging population. The B.E. Journal of Macroeconomics (advances) 12 (1).

Batista, C., Lacuesta, A., Vicente, P., 2012. Testing the brain gain hypothesis: micro evidence from Cape Verde. Journal of Development Economics 97 (1), 32-45.

Beine, M., Docquier, F., Ozden, C., 2011. Diasporas. Journal of Development Economics 95 (1), 30-41.

Benhabib, J., 1996. On the political economy of immigration. European Economic Review $40(9), 1737-1743$.

Bertoli, S., Brucker, H., 2011. Selective immigration policies, migrants' education and welfare at origin. Economics Letters 113 (1), 19-22.

Bhagwati, J., Hamada, K., 1974. The brain drain, international integration of markets for professionals and unemployment: a theoretical analysis. Journal of Development Economics 1 (1), 19-42.

Bhagwati, J., Hamada, K., 1982. Tax policy in the presence of emigration. Journal of Public Economics 18 (3), 291-317.

Bianchi, M., 2013. Immigration policy and self-selecting migrants. Journal of Public Economic Theory 15 (1), 1-23.

Billet, C., 2010. EC readmission agreements: A prime instrument of the external dimension of the eus fight against irregular immigration. an assessment after ten years of practice. European Journal of Migration and Law 12 (1), 45-79.

Borjas, B., 1987a. Self-selection and the earnings of immigrants. American Economic Review 77 (4), 531-553.

Borjas, G., 1995a. The economic benefits from immigration. Journal of Economic Perspectives $9(2), 3-22$. 
Borjas, G. J., 1987b. Immigrant, minorities, and labor market competition. Industrial and labor relations review 40 (3), 382-392.

Borjas, G. J., 1995b. The economic benefits from immigration. Journal of Economic Perspectives 9 (2), 3-22.

Borjas, G. J., 2011. Poverty and program participation among immigrant children. The Future of Children 21 (1), 247-266.

Bratsberg, B., Raaum, O., 2012. Immigration and wages: Evidence from construction. Economic Journal 122 (565), 1177-1205.

Burda, M., Wyplosz, C., 1992. Human capital, investment and migration in an integrated Europe. European Economic Review 36 (23), 677-684.

Card, D., 1990. The impact of the Mariel boatlift on the Miami labor market. Industrial and Labor Relations Review 43 (2), 245-257.

Carrington, W. J., Detragiache, E., Vishwanath, T., 1996. Migration with endogenous moving costs. American Economic Review LXXXVI, 909-930.

Cellini, R., 2007. Migration and welfare: a very simple model. Journal of International Development 19 (7), 885-894.

Clark, X., Hatton, T., Williamson, J., 2007. Explaining US immigration, 1971-1998. Review of Economics and Statistics 89 (2), 359-373.

Docquier, F., Rapoport, H., Salomone, S., 2012. Remittances, migrants' education and immigration policy: Theory and evidence from bilateral data. Regional Science and Urban Economics 42 (5, SI), 817-828.

Dustmann, C., Fadlon, I., Weiss, Y., 2011. Return migration, human capital accumulation and the brain drain. Journal of Development Economics 95 (1), 58-67.

Filer, R., May 1992. The effect of immigrant arrivals on migratory patterns of native workers. In: Immigration and the Workforce: Economic Consequences for the United States and Source Areas. NBER Chapters. National Bureau of Economic Research, Inc, pp. 245-270. 
Frontex, 2011. General report 2011. Tech. rep., Frontex.

Fuest, C., Thum, M., 2000. Welfare effects of immigration in a dual labor market. Regional Science and Urban Economics 30 (5), 551-563.

Gera, S., Songsakul, T., 2007. Benchmarking Canada's performance in the global competition for mobile talent. Canadian Public Policy - Analyse de politiques 33 (1), 63-84.

Giordani, P. E., Ruta, M., 2011. The immigration policy puzzle. Review of International Economics 19 (5), 922-935.

Heckman, J. J., 1979. Sample selection bias as a specification error. Econometrica 47 (1), $153-161$.

Ketkar, S. L., Ratha, D., 2010. Diaspora bonds: tapping the diaspora during difficult times. Journal of International Commerce, Economics and Policy 01 (02), 251-263.

LaLonde, R. J., Topel, R. H., 1991. Immigrants in the American labor market: quality, assimilation, and distributional effects. American Economic Review 81 (2), 297-302.

Marchiori, L., Shen, I.-L., Docquier, F., 2013. Brain drain in globalization: a general equilibrium analysis from the sending countries' perspective. Economic Inquiry 51 (2), $1582-1602$.

Mattoo, A., Neagu, I. C., Ozden, C., 2008. Brain waste? Educated immigrants in the US labor market. Journal of Development Economics 87, 255-269.

Mavroudi, E., Warren, A., 2013. Highly skilled migration and the negotiation of immigration policy: Non-EEA postgraduate students and academic staff at English universities. GEOFORUM 44, 261-270.

Miller, P. W., 1999. Immigration policy and immigrant quality: the Australian points system. American Economic Review 89 (2), 192-197.

Mincer, J., 1978. Family migration decisions. Journal of Political Economy 86 (5), 749 773. 
Mountford, A., 1997. Can a brain drain be good for growth in the source economy? Journal of Development Economics 53 (2), 287-303.

Mountford, A., Rapoport, H., 2011. The brain drain and the world distribution of income. Journal of Development Economics 95 (1), 4-17.

OECD, 2011. International Migration Outlook. OECD Publishing, Paris.

OECD, 2012. International Migration Outlook. OECD Publishing, Paris.

OECD, 2013. Recruiting Immigrant Workers: Germany 2013. OECD Publishing.

Ortega, F., Peri, G., 2009. The causes and effects of international migrations: evidence from OECD countries 1980-2005. NBER Working paper No. 14833.

Ostrovsky, Y., 2012. The dynamics of immigrant participation in entitlement programs: evidence from Canada, 1993-2007. Canadian Journal of Economics/Revue canadienne d'économique 45 (1), 107-136.

Rabe, B., 2011. Dual-earner migration. earnings gains, employment and self-selection. Journal of Population Economics 24, 477-497.

Razin, A., Sadka, E., 1999. Migration and pension with international capital mobility. Journal of Public Economics 74 (1), 141-150.

Schiff, M., 2002. Love thy neighbor: trade, migration, and social capital. European Journal of Political Economy 18 (1), 87-107.

Stark, O., Helmenstein, C., Prskawetz, A., 2004. Rethinking the brain drain. World Development 32 (1), 15-22.

Storesletten, K., 2000. Sustaining fiscal policy through immigration. Journal of Political Economy 108 (2), 300-323.

United Nations, 2011. International migrant stock by origin: the 2010 revision. Population Division, Migration Section.

Zimmermann, K. F., 1995. Tackling the European migration problem. Journal of Economic Perspectives 9 (2), 45-62. 


\section{Working Paper Series}

ISSN 1211-3298

Registration No. (Ministry of Culture): E 19443

Individual researchers, as well as the on-line and printed versions of the CERGE-EI Working Papers (including their dissemination) were supported from institutional support RVO 67985998 from Economics Institute of the ASCR, v. v. i.

Specific research support and/or other grants the researchers/publications benefited from are acknowledged at the beginning of the Paper.

(c) Dmytro Vikhrov, 2013

All rights reserved. No part of this publication may be reproduced, stored in a retrieval system or transmitted in any form or by any means, electronic, mechanical or photocopying, recording, or otherwise without the prior permission of the publisher.

Published by

Charles University in Prague, Center for Economic Research and Graduate Education (CERGE) and

Economics Institute of the ASCR, v. v. i. (EI)

CERGE-El, Politických vězňů 7, 11121 Prague 1, tel.: +420 224005 153, Czech Republic.

Printed by CERGE-EI, Prague

Subscription: CERGE-EI homepage: http://www.cerge-ei.cz

Phone: + 420224005153

Email: office@cerge-ei.cz

Web: http://www.cerge-ei.cz

Editor: Michal Kejak

The paper is available online at http://www.cerge-ei.cz/publications/working_papers/.

ISBN 978-80-7343-295-9 (Univerzita Karlova. Centrum pro ekonomický výzkum a doktorské studium)

ISBN 978-80-7344-287-3 (Národohospodářský ústav AV ČR, v. v. i.) 
CERGE-EI

P.O.BOX 882

Politických vězňů 7

11121 Praha 1

Czech Republic http://www.cerge-ei.cz 